\title{
Structure and Optical Properties of Al-doped ZnO Nanodrums as Anti-Reflection Coating Material in Solar Cells
}

\author{
Putri Luthfiana Sari ${ }^{1}$, Hanik Munawaroh ${ }^{1,2}$, Sayekti Wahyuningsih ${ }^{1, *}$, and Ari Handono Ramelan ${ }^{1}$ \\ ${ }^{1}$ Inorganic Material Research Group, Faculty of Mathematics and Natural Sciences, Sebelas Maret University, \\ Kentingan Jebres, Surakarta 57126, Indonesia \\ ${ }^{2}$ Chemistry Program, Graduate School of Sebelas Maret University, Kentingan Jebres, Surakarta 57126, Indonesia
}

* Corresponding author:

tel: $+62-81568455281$

email: sayekti@mipa.uns.ac.id

Received: September 30, 2018

Accepted: December 14, 2018

DOI: $10.22146 /$ ijc. 39260

\begin{abstract}
Al-doped $\mathrm{ZnO}$ (AZO) nanodrums were synthesized using hydrothermal method at $80{ }^{\circ} \mathrm{C}$ for $20 \mathrm{~h}$ using precursor $\mathrm{Zn}\left(\mathrm{CH}_{3} \mathrm{COO}\right)_{2} \cdot 2 \mathrm{H}_{2} \mathrm{O}$ and $\mathrm{Al}(\mathrm{OH})\left(\mathrm{CH}_{3} \mathrm{COO}\right)_{2}$ as a dopant by varying the addition of $A l$ concentrations in the range of $0,1,5,10,15$, and $20 \mathrm{mM}$. The variation of Al can affect the crystal growths, structure properties, and optical properties of $\mathrm{ZnO}$. Addition of Al can inhibit the crystal growth with the decrease of the crystal size ranging from about 43.46 to $37.21 \mathrm{~nm}$. Morphology of Al variation doped $\mathrm{ZnO}$ of Al was studied using a Scanning Electron Microscope (SEM) and Transmission Electron Microscope (TEM) and showed nanodrums morphology. Optical properties of thin film AZO was evaluated using UV-Visible spectrophotometer. The crystallite size of AZO can affect optical properties with the occurrence of blue shift. The transmission spectra showed that AZO has $\sim 85 \%$ transparency in the visible spectra with a sharp peak in the UV region. AZO with the addition of $20 \mathrm{mM} \mathrm{Al}$ has the largest transmittance and the lowest reflectance. The thin film with transparent properties is a good candidate for application in the dye-sensitized solar cells, such as anti-reflection coating. AZO (20 mM of Al) was prepared as anti-reflection on the DSSCs system. The best efficiency of DSSCs performance was examined by varying the thickness of the layers of AZO and pointed an efficiency improvement up to 18.29 times.
\end{abstract}

Keywords: Al-doped $\mathrm{ZnO}$; structure properties; optical properties; anti-reflection coating; DSSCs

\section{- INTRODUCTION}

Dye-sensitized solar cells (DSSCs) is a third generation solar cell which was firstly introduced by Grätzel in 1991 [1]. DSSCs have continued to be developed until now. On DSSCs system, abundant sunlight was reflected, so the efficiency is still low. Scattering of photons in the DSSCs system causes the efficiency of solar cells to be less optimum. Therefore, they need an anti-reflecting material which can increase light harvesting from the thin layers [2].

$\mathrm{ZnO}$ is a semiconductor material that has many functions in optoelectronic application [3]. $\mathrm{ZnO}$ has about $3.37 \mathrm{eV}$ (at $300 \mathrm{~K}$ ) band gap energy [4]. It is transparent in visible light areas and has good adhesion and hardness properties. $\mathrm{ZnO}$ has a refractive index value of \pm 2 which is convenient to index requirement of antireflection coating solar cells [5-6]. Improvement of the optical, physical and electrical properties of $\mathrm{ZnO}$ can be conducted using the doping method [7] in order to optimize the transmitted light. Doping means adding impurity atoms (dopant) into the semiconductor crystal structure in order to improve the properties of the semiconductor. The metals such as $\mathrm{Ga}$, In, Sn, Mg, B, and $\mathrm{Al}$ were commonly used as substituted dopants into the $\mathrm{ZnO}$ structure [8].

Aluminum ( $\mathrm{Al}$ ) is a dopant metal that is able to increase the electrical conductivity of $\mathrm{ZnO}$ because it has a smaller ionic radius than $\mathrm{ZnO}$, and it is cheaper than other materials [9]. Sengupta et al. reported that aluminum as a $\mathrm{ZnO}$ dopant can improve optical 
properties and decrease band gap energy of $\mathrm{ZnO}$ [10]. Recently, $\mathrm{ZnO}$ which is doped with $\mathrm{Al}$ metals is known as Al-doped $\mathrm{ZnO}$ (AZO).

In this study, we have prepared AZO with a variation of $\mathrm{Al}$ concentrations using a simple and low-cost hydrothermal method. The effect of $\mathrm{Al}$ dopant on structural and optical properties of AZO was investigated. The best performing of AZO was applied as an antireflection to the DSSCs (dye-sensitized solar cells).

\section{- EXPERIMENTAL SECTION}

\section{Materials}

The materials used in this research were $\mathrm{Zn}\left(\mathrm{CH}_{3} \mathrm{COO}\right)_{2} \cdot 2 \mathrm{H}_{2} \mathrm{O} \quad$ (Aldrich), $\mathrm{Al}(\mathrm{OH})\left(\mathrm{CH}_{3} \mathrm{COO}\right)_{2}$ (Aldrich), Polyethylene glycol $1000\left(\mathrm{HO}\left(\mathrm{C}_{2} \mathrm{H}_{4} \mathrm{O}\right)_{n} \mathrm{H}\right.$ (Merck), Ethanol (Merck), Ammonia (Merck), KI (Merck), $\mathrm{I}_{2}$ (Merck), Dye Ruthenium N3 (Aldrich), paste of $\mathrm{TiO}_{2} 18$ NRT (Dyesol), Platinum paste (Dyesol). Distilled water was obtained from MIPA Terpadu laboratory.

\section{Instrumentation}

The characterization of crystal structure and crystallite size of AZO were done using X-Ray Diffraction (XRD) Bruker type D8 with anode $\mathrm{Cu}$. The Morphology of AZO was analyzed by Scanning Electron Microscopy (SEM) quanta 250 and Transmission Electron Microscope (TEM) JEOL JEM 1400. The optical properties of AZO were characterized by UV-Visible spectrophotometer Lambda 25 Perkin Elmer. The electrical properties and the efficiency of solar cells were characterized using Current-Voltage (IV) meters Keithley 2602 A. Crystallite size of AZO was calculated by DebyeScherrer in Eq. (1).

$\mathrm{D}(\mathrm{nm})=\frac{\mathrm{k} \lambda}{\mathrm{B} \cos \theta}$

where $\mathrm{D}=$ crystallite size $(\mathrm{nm}), \mathrm{k}=$ constant value $(0.9), \lambda$ $=$ the X-ray wavelength $(0.15406 \mathrm{~nm}), \mathrm{B}=$ full width at half the maximum (FWHM) in radians and $\theta$ is the Braggs' angle (deg).

\section{Procedure}

\section{Synthesis of AZO}

$\mathrm{AZO}$ was synthesized from $0.1 \mathrm{M}$ $\mathrm{Zn}\left(\mathrm{CH}_{3} \mathrm{COO}\right)_{2} \cdot 2 \mathrm{H}_{2} \mathrm{O}$ and dopant of $\mathrm{Al}(\mathrm{OH})\left(\mathrm{CH}_{3} \mathrm{COO}\right)_{2}$, as precursors. The precursors were dissolved in distilled water. $\mathrm{Al}(\mathrm{OH})\left(\mathrm{CH}_{3} \mathrm{COO}\right)_{2}$ initial concentration was varied as $1,5,10,15$, and $20 \mathrm{mM}$. Polyethylene Glycol (PEG) $10000.1 \mathrm{M}$ was then added to the solution. The mixture was stirred for $60 \mathrm{~min}$. Then, the addition of ammonia to the solution was conducted until the $\mathrm{pH}$ of the solution became neutral [7]. The solution was put into a Teflon-lined autoclave for being processed hydrothermally at $80{ }^{\circ} \mathrm{C}$ for $20 \mathrm{~h}$. The precipitate was washed using ethanol and distilled water and then dried at $60^{\circ} \mathrm{C}$. The obtained AZO powder was calcinated at $600^{\circ} \mathrm{C}$ for $2 \mathrm{~h}$.

\section{DSSCs fabrication}

The platinum electrode was coated to a conductive thin film, and the working electrode was arranged with a layer of $\mathrm{AZO} / \mathrm{TiO}_{2} /$ dye. Then, the working electrode was put on the top of the platinum electrode. Both of electrodes were arranged to be sandwich-form-DSSCs. An electrolyte solution was then dropped into the gap of the sandwich. The solar cells performance was characterized using Keithley 2602 A. The efficiency of DSSCs was calculated by Eq. (2).

$\eta=\frac{P_{\max }}{P_{\text {in }}} \times 100 \%=\frac{V_{\text {oc }} \times I_{\text {sc }} \times F F}{P_{\text {in }}} \times 100 \%$

where $\eta=$ efficiency of solar cells (\%), $P_{\max }=$ the maximum electrical power output $\left(\mathrm{W} / \mathrm{m}^{2}\right), \mathrm{P}_{\text {in }}=$ the solar power input $\left(\mathrm{W} / \mathrm{m}^{2}\right), \mathrm{V}_{\mathrm{oc}}=$ the open-circuit voltage $(\mathrm{V}), \mathrm{I}_{\mathrm{sc}}=$ the short-circuit current density $\left(\mathrm{A} / \mathrm{m}^{2}\right)$, FF (fill factor) $=$ index of loss electric generation.

\section{- RESULTS AND DISCUSSION}

\section{Structure Properties of AZO}

Structure of AZO was analyzed from the pattern of XRD peaks (Fig. 1). Characterization results from XRD showed the peaks fit ICSD standard No. 67848 with the 


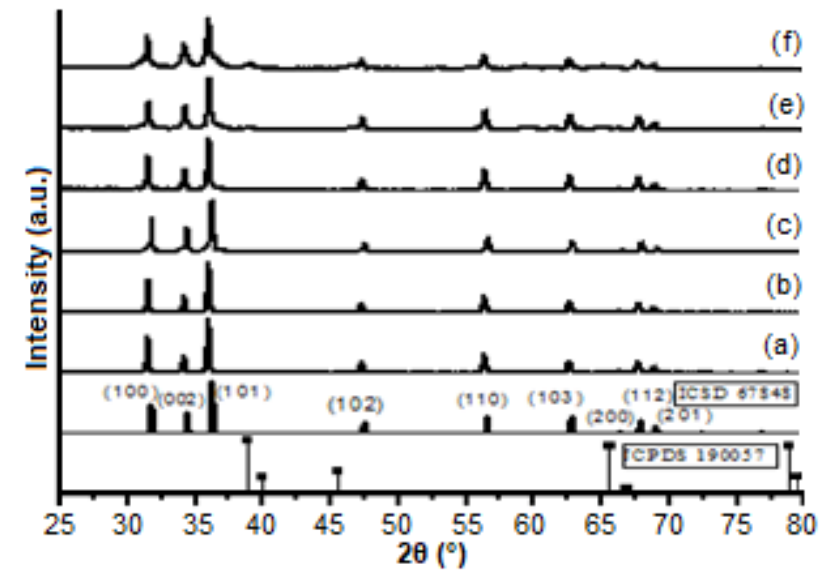

Fig 1. XRD pattern of $A Z O$ with $\mathrm{Al}$ variation of (a) 0 , (b) 1, (c) 5 , (d) 10 , (e) 15 , and (f) $20 \mathrm{mM}$

hexagonal wurtzite crystal structure. The main peak of AZO showed lattice planes of (100), (002), (101), (102), (110), (103), (200), (112), and (201) of hexagonal wurtzite of $\mathrm{ZnO}$. However, in the $\mathrm{AZO}$ with $\mathrm{Al}$ variation of 15 and $20 \mathrm{mM}$, there were peaks that not coincide to the ICSD. Those incompatible peaks were presented at $2 \theta$ about 38 $39^{\circ}$ as the peak of $\mathrm{Al}$ according to JCPDS 19-0057. The presence $\mathrm{Al}$ peak is due to the addition of a considerable $\mathrm{Al}$ concentration of 15 and $20 \mathrm{mM}$.

The captured peak shift in the plane of (100) (002) and (101) was shown in Fig. 2. The shift of the plane (002) occurred to a larger diffraction angle with increasing of dopant $\mathrm{Al}$, except for the addition of $5 \mathrm{mM} \mathrm{Al}$. Meanwhile, the peak shift of (100) and (101) plane was not significant. The peak shift to larger diffraction angle indicated the inclusion of dopant $\mathrm{Al}^{3+}$ ions which have a smaller radius than $\mathrm{Zn}^{2+}$ ions into the lattice of $\mathrm{ZnO}$ [1112]. Meanwhile, the shifted peak to a smaller diffraction angle was caused by a tensile voltage that raised distortion in the lattice of $\mathrm{ZnO}$.

The crystallite size was calculated using the DebyeScherrer equation [13]. The results of the crystallite size showed that the greater of $\mathrm{Al}$ concentration was able to decrease the crystallite size (Table 1). AZO crystallite size decreased because the radius of $\mathrm{Zn}^{2+}$ ions was greater than $\mathrm{Al}^{3+}$ ions $\left(\mathrm{r}_{\mathrm{Al}}=0.0054 \mathrm{~nm}\right.$ and $\left.\mathrm{r}_{\mathrm{Zn}}=0.074 \mathrm{~nm}\right)$ and rendered the substitution of $\mathrm{Al}$ ions to $\mathrm{Zn}$ in the $\mathrm{ZnO}$ lattice [14-15]. The substitution caused the cell unit of $\mathrm{ZnO}$ to shrink [16].
Morphological appearance of AZO was interpreted by SEM image (Fig. 3). The morphology and particle shape of AZO was nanodrums with the hexagonal cross-sectional shape. The use of Polyethylene glycol 1000 as non-ionic surfactant affected the morphology of AZO at low temperature in the hydrothermal process. This result was similar to the

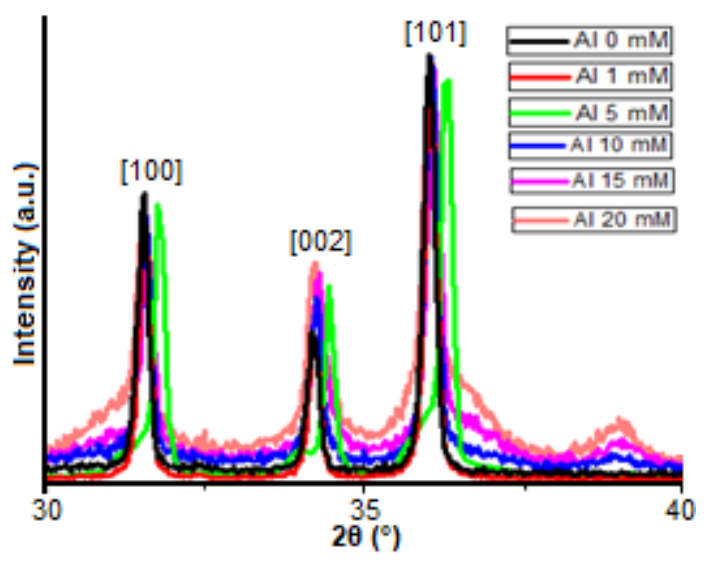

Fig 2. The peak shift of AZO

Table 1. Crystallite size of AZO

\begin{tabular}{cc}
\hline $\begin{array}{c}\text { Al Concentration } \\
(\mathrm{mM})\end{array}$ & $\begin{array}{c}\text { Crystallite size } \\
(\mathrm{D})(\mathrm{nm})\end{array}$ \\
\hline 0 & 43.46 \\
1 & 43.00 \\
5 & 42.86 \\
10 & 41.40 \\
15 & 40.10 \\
20 & 37.21 \\
\hline
\end{tabular}

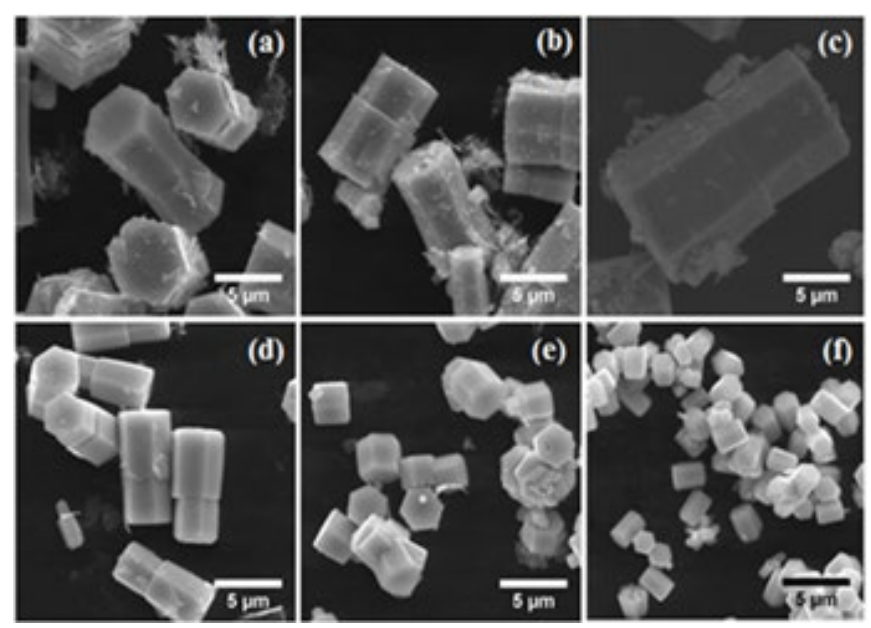

Fig 3. SEM image of $A Z O$ with $\mathrm{Al}$ variation of (a) 0 , (b) 1, (c) 5 , (d) 10 , (e) 15 , and (f) $20 \mathrm{mM}$ 
Table 2. The length and diameter of AZO

\begin{tabular}{ccc}
\hline $\begin{array}{c}\text { Al Concentration } \\
(\mathrm{mM})\end{array}$ & $\begin{array}{c}\text { Length } \\
(\mu \mathrm{m})\end{array}$ & $\begin{array}{c}\text { Diameter } \\
(\mu \mathrm{m})\end{array}$ \\
\hline 0 & 8.36 & 5.28 \\
1 & 7.95 & 4.93 \\
5 & 16.06 & 8.53 \\
10 & 7.24 & 3.35 \\
15 & 2.24 & 3.00 \\
20 & 2.19 & 1.59 \\
\hline
\end{tabular}

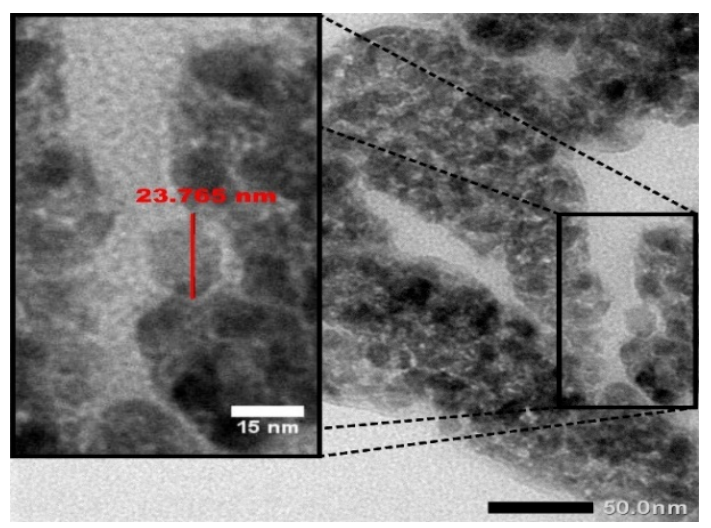

Fig 4. TEM image of AZO with a concentration of $20 \mathrm{mM}$ $\mathrm{Al}$

previous research of Jung and Moo (2014) [17], which stated that the addition of non-ionic surfactants could influence the formation of $\mathrm{ZnO}$ nanodrums.

The average particle sizes of AZO seemed to be smaller, but with the addition of $\mathrm{Al} 5 \mathrm{mM}$ (Fig. 3(c)), the AZO particle size appeared larger. The differences level of polarity (polar face) on the surface of AZO caused greater

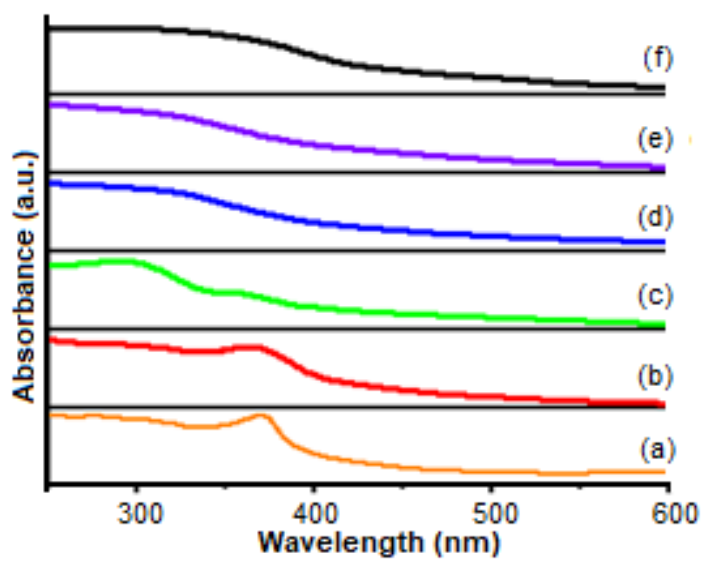

Fig 5. Absorbance spectra of AZO with Al variation of (a) 0, (b) 1, (c) 5, (d) 10, (e) 15, and (f) $20 \mathrm{mM}$ growth of particle sizes. Meanwhile, the addition of 10, 15 , and $20 \mathrm{mM} \mathrm{Al}$ has contributed to the decrease in length and diameter (Table 2). According to Ridhuan et al. [18], this probably occurred when both polar faces of $\mathrm{ZnO}$ crystal contain a high amount of $\left[\mathrm{Al}(\mathrm{OH})_{4}\right]^{-}, \mathrm{Al}^{3+}$ was adsorbed to its surface attracting each other and inhibiting the growth of $\mathrm{ZnO}$, and the particle size became smaller. Imaging AZO morphology using TEM (Fig. 4) represented surface of nanodrums clearly. The particle size of AZO (Al $20 \mathrm{mM}$ ) is around $23.765 \mathrm{~nm}$. TEM image showed that the $\mathrm{ZnO}$ nanodrum was successfully synthesized.

\section{Optical Properties of AZO}

Absorbance analysis of AZO (Fig. 5) showed that the addition of Al-dopant stimulated the shifted peak of the AZO to the smaller wavelength (a blue shift phenomenon). The UV-Visible absorption spectra of AZO was in the range $250-369 \mathrm{~nm}$ coinciding to a characteristic of absorption spectra for $\mathrm{ZnO}$ with hexagonal structures located in the wavelength ranging from 200-400 $\mathrm{nm}$ [19].

The transmittance spectra of AZO in Fig. 6 displayed transmittance value in visible light areas in the range $50-90 \%$. The best transmittance value was AZO in addition of $20 \mathrm{mM} \mathrm{Al}$ because it has smaller diameter and length. The small particle size enacted the surface area of larger particles to increase the transmitted light [20].

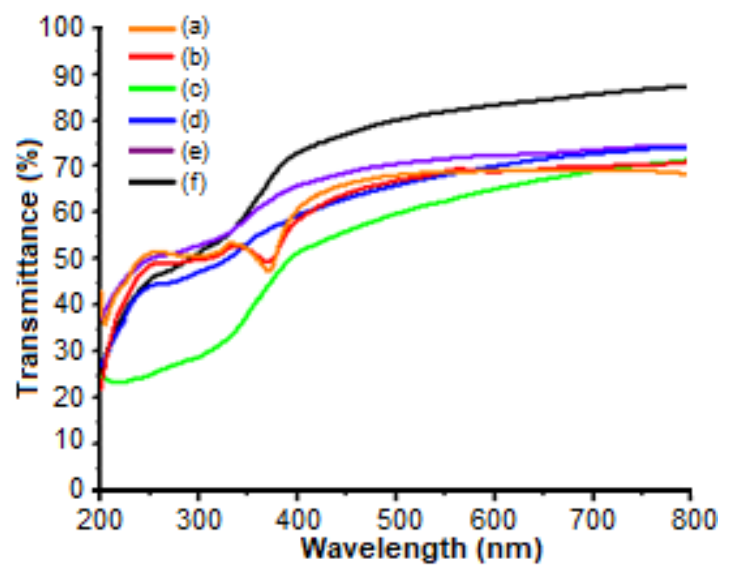

Fig 6. Transmittance spectra of $\mathrm{AZO}$ with $\mathrm{Al}$ variation of (a) 0, (b) 1, (c) 5, (d) 10, (e) 15, and (f) $20 \mathrm{mM}$ 


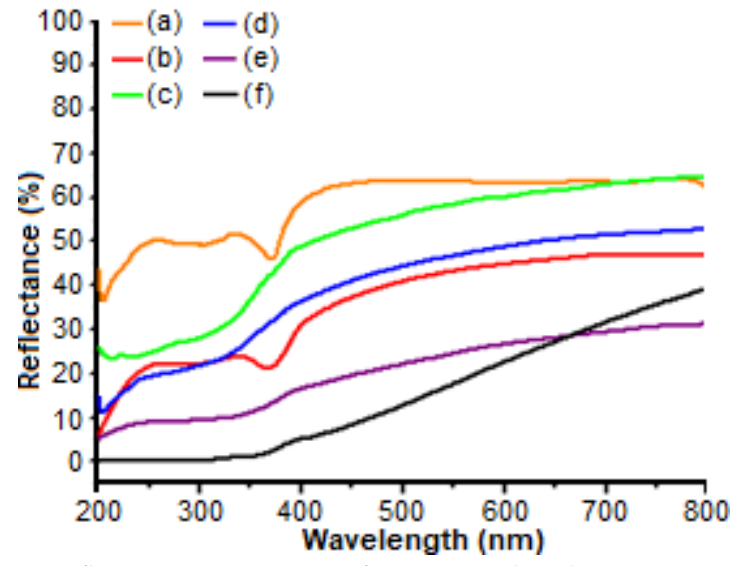

Fig 7. Reflectance spectra of $\mathrm{AZO}$ with $\mathrm{Al}$ variation of (a) 0 , (b) 1 , (c) 5 , (d) 10, (e) 15, and (f) 20

The addition of $\mathrm{Al}$ in the $\mathrm{ZnO}$ structure caused a decrease of reflectance value (Fig. 7). The decrease of AZO reflectance was due to differences in light scattering from the effect of different dopants concentrations. The lowest reflectance was obtained in the AZO with the addition of $20 \mathrm{mM} \mathrm{Al}$.

The best optical property was AZO with a concentration of $20 \mathrm{mM} \mathrm{Al}$. Then, the band gap energy of AZO calculated with Kubelka-Munk equation showed that the addition of $\mathrm{Al}$ dopant $1,5,15$, and $20 \mathrm{mM}$ could decrease band gap energy and yield defect in $\mathrm{ZnO}$ crystals. The band gap energy of AZO 0 and $20 \mathrm{mM}$ were 3.10 and $3.085 \mathrm{eV}$, respectively.

\section{AZO Nanodrums as Anti-Reflection Coating on DSSCs}

AZO nanodrums with $\mathrm{Al}$ concentration of $20 \mathrm{mM}$ are used as anti-reflection since they have a good crystal structure, the lowest reflectance, and the best transmittance among others, whereas $\mathrm{ZnO}$ (AZO $0 \mathrm{mM}$ ) was used as the control of anti-reflection. Deposition of AZO layer on DSSCs varied in thickness of 1,2 and 3 layers. The best efficiency of DSSCs performance was achieved by utilizing 1 layer of AZO anti-reflection (Fig. 8), where it improved efficiency up to 18.29 times compared with $\mathrm{ZnO}$ (AZO $0 \mathrm{mM}$ ).

\section{- CONCLUSION}

Al-doped $\mathrm{ZnO}(\mathrm{AZO})$ nanodrums were successfully synthesized using the hydrothermal method with the

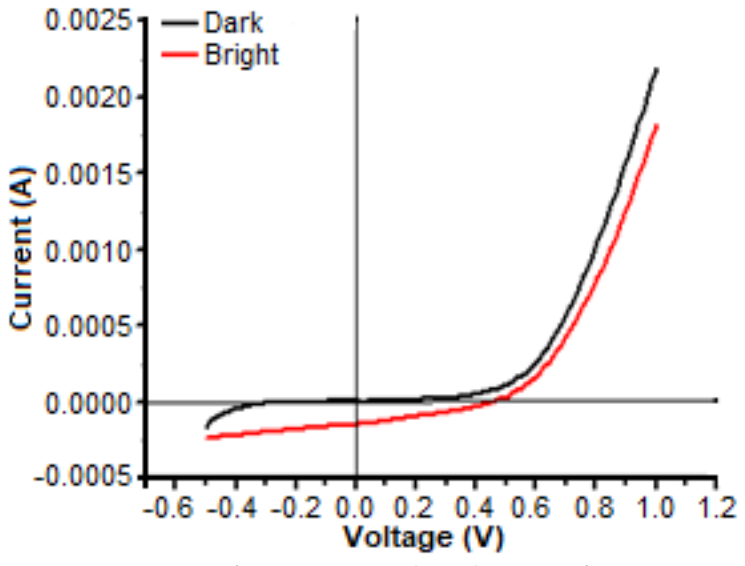

Fig 8. I-V curve of DSSCs with 1 layer of AZO as antireflection

addition of varied $\mathrm{Al}$ dopant in the range of $0,1,5,10$, $15,20 \mathrm{mM}$. The variation of $\mathrm{Al}$ affected the structure and optical properties of AZO. Increasing concentrations of $\mathrm{Al}$ decreased the crystallite size. The optical properties of AZO showed the occurrence of blue shifts in the wavelength 250-369 nm, the decrease of reflectance value and the increase of transmittance value. The addition of 1 layer AZO as an anti-reflection coating on DSSCs provided the best performance as showed by efficiency improvement up to 18.29 times.

\section{- ACKNOWLEDGMENTS}

The Authors would like to thank Sebelas Maret University for support funding through Penelitian Mandatory (Mandatory Research) No. 543/UN27.21/PP/2018.

\section{- REFERENCES}

[1] Grätzel, M., 2003, Dye-sensitized solar cells, J. Photochem. Photobiol., C, 4 (2), 145-153.

[2] Wahyuningsih, S., Fadillah, G., Hidayat, R., and Ramelan, A.H., 2016, Thin film $\mathrm{ZnO}$ coated on $\mathrm{FTO} / \mathrm{TiO}_{2}$ as an anti-reflection coating for enhancing visible light harvesting in dye sensitized solar cells system, Procedia Chem., 19, 632-637.

[3] Putri, A.A., Wahyuningsih, T.D., and Kartini, I., 2011, Hydrothermal synthesis of rod and chrysanthemum like nanostructured $\mathrm{ZnO}$, Indones. J. Chem., 11 (2), 131-134. 
[4] Choi, K., Kang, T., and Oh, S.G., 2012, Preparation of disk-shaped $\mathrm{ZnO}$ particles using a surfactant and their PL properties, Mater. Lett., 75, 240-243.

[5] Aslan, M.H., Oral, A.Y., Menşur, E., Gül, A., and Başaran, E., 2004, Preparation of c-axis-oriented zinc-oxide thin films and the study of their microstructure and optical properties, Sol. Energy Mater. Sol. Cells, 82 (4), 543-552.

[6] Vinodkumar, R., Lethy, K.J., Beena, D., Satyanarayana, M., Jayasree, R.S., Ganesan, V., Nayar, V.U., and Pillai, V.P.M., 2009, Effect of thermal annealing on the structural and optical properties of nanostructured zinc oxide thin films prepared by pulsed laser ablation, Sol. Energy Mater. Sol. Cells, 93 (1), 74-78.

[7] Kim, C.E., Moon, P., Kim, S., Myoung, J.M., Jang, H.W., Bang, J., and Yun, I., 2010, Effect of carrier concentration on optical bandgap shift in $\mathrm{ZnO}: \mathrm{Ga}$ thin films, Thin Solid Films, 518 (22), 6304-6307.

[8] Yun, S., Lee, J., Yang, J., and Lim, S., 2010, Hydrothermal synthesis of Al-doped AZO nanorod arrays on Si substrate, Physica B, 405 (1), 413-419.

[9] Nunes, P., Fortunato, E., Tonello, P., Fernandes, F.B., Vilarinho, P., and Martins, R., 2002, Effect different dopant elements on the properties of $\mathrm{ZnO}$ thin films, Vacuum, 64 (3-4), 281-285.

[10] Sengupta, D., Mondal, B., and Mukherjee, K., 2017, Genesis of flake-like morphology and dye-sensitized solar cell performance of AZO particles: A study, J. Nanopart. Res., 19 (3), 100.

[11] Jeong, C., Kim, H., Chang, D., and Kamisako, K., 2008, Effect on $\mathrm{Al}_{2} \mathrm{O}_{3}$ doping concentration of $\mathrm{RF}$ magnetron sputtered $\mathrm{ZnO}: \mathrm{Al}$ film for solar cell applications, Jpn. J. Appl. Phys., 47 (7), 5656-5658.

[12] Zhang, P., Hong, R.Y., Chen, Q., and Feng, W.G., 2014, On the electrical conductivity and photocatalytic activity of aluminium-doped zinc oxide, Powder Technol., 253, 360-367.

[13] Monshi, A., Foroughi, M.R., and Monshi, M.R., 2012, Modified Scherrer equation to estimate more accurately nano-crystallite size using XRD, World J. Nano Sci. Eng., 2 (3), 154-160.

[14] Ghazai, A.J., Salman, E.A., and Jabbar, Z.A., 2016, Effect of aluminum doping on zinc oxide thin film properties synthesis by spin coating method, $A m$. Sci. Res. J. Eng., Technol., Sci., 26 (3), 202-211.

[15] Sahay, P.P., and Nath, R.K., 2008, Al-doped zinc oxide thin films for liquid petroleum gas (LPG) sensors, Sens. Actuators, B, 133 (1), 222-227.

[16] Shui, A., Wang, S., Wang, H., and Cheng, X., 2009, Preparation and properties for aluminium doped zinc oxide powders with the coprecipitation method, J. Ceram. Soc. Jpn., 117 (5), 703-705.

[17] Jung, M.H. and Chu, M.J., 2014, Synthesis of hexagonal $\mathrm{ZnO}$ nanodrums, nanosheets and nanowires by the ionic effect during the growth of hexagonal $\mathrm{ZnO}$ crystals, J. Mater. Chem. C, 2 (32), 6675-6682.

[18] Ridhuan, N.S., Lockman, Z., Aziz, A.A., and Razak, K.A., 2016, Properties of Al-doped $\mathrm{ZnO}$ nanorods synthesized using the low-temperature hydrothermal method, Mater. Sci. Forum, 846, 459-464.

[19] Irannejad, A., Janghorban, K., Tan, O.K., Huang, H., Lim, C.K., Tan, P.Y., Fang, X., Chua, C.S., Maleksaeedi, S., Hejazi, S.M.H., Shahjamali, M.M., and Ghaffari, M., 2011, Effect of the $\mathrm{TiO}_{2}$ shell thickness on the dye-sensitized solar cells with $\mathrm{ZnO}_{-} \mathrm{TiO}_{2}$ core-shell nanorod electrodes, Electrochim. Acta, 58, 19-24.

[20] Hong, C.S., Park, H.H., Moon, J., and Park, H.H., 2006, Effect of metal (Al, Ga, and In)-dopants and/or Ag-nanoparticles on the optical and electrical properties of $\mathrm{ZnO}$ thin films, Thin Solid Films, 515 (3), 957-960. 